\title{
Isolation of cancer progenitor cells from cancer stem cells in gastric cancer
}

\author{
ZHIYANG SHANG ${ }^{1}$, YINGXIN XU ${ }^{2}$, WENTAO LIANG ${ }^{2}$, KAI LIANG $^{2}$, \\ XIANG HU ${ }^{1}$, LEI WANG ${ }^{1}$, ZHENYU ZOU ${ }^{1}$ and YUE MA ${ }^{1}$ \\ ${ }^{1}$ Department of General Surgery, The First Affiliated Hospital of Dalian Medical University, Dalian, \\ Liaoning 116011; ${ }^{2}$ Institute of General Surgery, Chinese PLA General Hospital, Beijing 100853, P.R. China
}

Received December 7, 2015; Accepted November 29, 2016

DOI: $10.3892 / \mathrm{mmr} .2017 .6423$

\begin{abstract}
The success of cancer treatment may depend on the complete elimination of cancer stem cells (CSCs). However, data regarding the current characterization of CSCs in different types of tumor are inconsistent, possibly due to the mixture of CSCs with cancer progenitor cells (CPCs). Therefore, it is important to exclude CPCs for the characterization of CSCs. The present study aimed to characterize gastric cancer stem cells (GCSC) by separating GCPC from gastric progenitor cells (GCSC) with flow cytometry. In total, 615 murine gastric cancer (GC) cells were divided into aldehyde dehydrogenase $(\mathrm{ALDH})^{\text {high }}, \mathrm{ALDH}^{\text {low }}$ and $\mathrm{ALDH}^{\text {neg }}$ groups by flow cytometry according to their ALDH activity. With decreased ALDH activity, the expression levels of stemness-associated markers, $\mathrm{CD}_{133^{+}}$, octamer-binding transcription factory-4 and sex determining region Y-box 2 decreased. The $\mathrm{ALDH}^{\text {high }}$ and $\mathrm{ALDH}^{\text {low }}$ cells proliferated and formed tumor spheres in ultra-low adhesion medium without serum, however, the latter formed larger tumor spheres. In mice transplanted with 5,000 cells, the rate of tumor formation in the $\mathrm{ALDH}^{\text {low }}$ group was significantly higher, compared with that in the $\mathrm{ALDH}^{\text {high }}$ group. Of note, an increased number of mice developed tumors in the $\mathrm{ALDH}^{\text {high }}$ group 16 weeks following the injection of 500 cells, whereas tumors appeared at 8 weeks in the ALDH ${ }^{\text {low }}$ group. The mice in the $\mathrm{ALDH}^{\text {neg }}$ group exhibited less tumor formation under these conditions. These results demonstrated that $\mathrm{ALDH}^{\text {high }}$ cells had characteristics of GCSCs with a high level of self-renewal ability, but were in a relative resting stage. The ALDH ${ }^{\text {low }}$ cells had characteristics of GCPCs with limited self-renewal ability, but were in a rapid proliferation stage. These findings suggested that the separation of GCPCs from
\end{abstract}

Correspondence to: $\mathrm{Dr}$ Xiang $\mathrm{Hu}$, Department of General Surgery, The First Affiliated Hospital of Dalian Medical University, 222 Zhongshan Road, Dalian, Liaoning 116011, P.R. China

E-mail: shangzhiyang85@163.com

Key words: cancer stem cells, cancer progenitor cells, gastric cancer, aldehyde dehydrogenase, differentiation levels
GCSCs is important for elucidating the biology of GCSCs and identifying strategies to eliminate GCSCs in GC.

\section{Introduction}

Gastric cancer (GC) is one of the most common types of cancer worldwide and its mortality rate is the second highest among all malignancies (1). Recurrence following treatment is the primary cause of GC-associated mortality (2). Therefore, it is important to elucidate the mechanism of drug resistance and identify strategies to prevent the recurrence of GC following treatment. Cancer stem cells (CSCs) are the origin of uncontrolled cancer cell growth. The elimination of CSCs is considered the only way to fully eradicate tumors (3). Thus, identification, isolation and validation of gastric CSCs (GCSCs) may provide novel clues for GC treatment. However, data currently available regarding the isolation, characterization and functional investigations of CSCs are inconsistent and controversial, particularly in GCSCs. For example, Fukuda et al (4) obtained GCSCs from MKN-45 cells via side population (SP) cell sorting, whereas Zhang et al (5), found that the SP cell sorting method did not apply to all types of GC cell. Takaishi et al (6) isolated GCSCs from MKN-45, MKN-74 and N-87 GC cell lines when CD44 ${ }^{+}$ was used as a marker, however, no significant differences in tumor formation were found between the SP cells and non-SP cells. Others have reported that $\mathrm{CD} 44^{+}$cells show no correlation with the malignancy of GC cells (7). Thus, it is important to isolate pure GCSCs by applying the appropriate methods and markers.

The CSC theory holds that the development of tumors derives from CSCs with unlimited self-renewal ability to generate cancer progenitor cells (CPCs), which have limited self-renewal ability and differentiate into large quantities of regular cancer cells. However, the majority of studies on CSCs do not distinguish between CSCs and CPCs in cell populations with stemness, as CPCs also have self-renewal ability and stemness (8). As CSCs and CPCs may have significantly different biological characteristics, it is important to distinguish between CSCs and CPCs in stem-like cells.

Aldehyde dehydrogenase (ALDH) is a marker, which can be used to distinguish between the high degree of stemness of CSCs and the low degree of stemness of CPCs from stem-like 
cell populations. ALDH is an enzyme, which detoxifies and is important in stem cell proliferation. Its activity reflects the degree of cell stemness (9-13). Accordingly, several studies have acquired $\mathrm{CSCs}$ from $\mathrm{ALDH}^{+}$tumor cells by assessing ALDH activity (14-19). Although these studies did not distinguish between CSCs and CPCs in acquired stem-like cells, this method can detect the levels expression of ALDH in $\mathrm{ALDH}^{+}$ cell populations. Consequently, the present study hypothesized that pure CSCs are $\mathrm{ALDH}^{+}$cells with high ALDH activity and $\mathrm{CPCs}$ are $\mathrm{ALDH}^{+}$cells with low ALDH activity. In our previous study, ALDH high $\left(\mathrm{ALDH}{ }^{\text {high }}\right)$, low $\left(\mathrm{ALDH}^{\text {low }}\right)$ and negative $\left(\mathrm{ALDH}^{\mathrm{neg}}\right)$ subgroups we successfully sorted in H22 mouse hepatic cancer cells, and it was found that the characteristics of these cells were similar to those of CSCs, CPCs and regular cancer cells, respectively (20). These results suggested that sorting of $\mathrm{ALDH}^{\text {high }}$ and $\mathrm{ALDH}^{\text {low }}$ populations may assist in isolating and characterizing GCSCs and gastric CPCs (GCPCs).

In order to elucidate the causes of the conflicting results in previous studies of gastric cancer stem cells, in the present study $\mathrm{ALDH}^{\text {high }}, \mathrm{ALDH}^{\text {low }}$ and $\mathrm{ALDH}^{\text {neg }}$ were successfully sorted from 615 murine GC (MFC) cells using an ALDH assay. It was found that $\mathrm{ALDH}^{\text {high }}$ and $\mathrm{ALDH}^{\text {low }}$ cells exhibited characteristics of GCSCs and GCPCs, respectively. These findings suggested that the MFC stem-like cells had two cell subpopulations with distinct characteristics and that CPCs require exclusion for the investigation of CSCs.

\section{Materials and methods}

Cell lines and cell culture. MFC cells were purchased from the Chinese Academy of Sciences Typical Culture Preservation Committee Cell Bank (Shanghai, China). The cells were cultured in humidified air at $37^{\circ} \mathrm{C}$ with $5 \% \mathrm{CO}_{2}$ in RPMI-1640 (Sigma-Aldrich; Merck Millipore; Darmstadt, Germany) supplemented with $10 \%$ fetal bovine serum (Gibco; Thermo Fisher Scientific, Inc., Waltham, MA, USA), 100 U/ml penicillin and $100 \mathrm{mg} / \mathrm{ml}$ streptomycin (Invitrogen; Thermo Fisher Scientific, Inc.).

ALDH assay and cell sorting. ALDH activity was determined using an ALDEFLUOR ${ }^{\mathrm{TM}}$ assay (Stemcell Technologies, Inc., Vancouver, BC, Canada) according to the manufacturer's protocol. Briefly, the cells were suspended in ALDEFLUOR ${ }^{\mathrm{TM}}$ assay buffer $\left(2 \times 10^{6}\right.$ cells $\left./ \mathrm{ml}\right)$. The ALDH reaction substrate, BODIPY-aminoacetaldehyde, was added to the experimental groups, whereas ALDH substrate and the inhibitor, diethylaminobenzaldehyde, were added to the control groups, followed by incubation at $37^{\circ} \mathrm{C}$ for $40 \mathrm{~min}$ in the dark. An Accuri C6 flow cytometer (BD Biosciences, Franklin Lakes, NJ, USA) was used to detect ALDH activity, and analyze the proportion of $\mathrm{ALDH}^{+}$and $\mathrm{ALDH}^{-}$cells. Cell sorting was performed as previously described (20). Briefly, the $1 \%$ of viable cells with the highest fluorescence intensity among the $\mathrm{ALDH}^{+}$cell population were selected as $\mathrm{ALDH}^{\text {high }}$ cells, the $1 \%$ with the lowest fluorescence intensity among the $\mathrm{ALDH}^{+}$cell population were selected as the $\mathrm{ALDH}^{\text {low }}$ cell population and the $1 \%$ with the lowest fluorescence intensity among the $\mathrm{ALDH}^{-}$cell population were selected as $\mathrm{ALDH}^{\text {neg }}$ cells. Flow cytometry was used to select these cells on a FACS Aria II flow cytometer (BD Biosciences).
Flow cytometry. The cells were suspended in phosphate-buffered saline (PBS; $2 \times 10^{6}$ cells/ml). Rat anti-CD133-phycoerythrin antibody (clone 13A4; 1:50; cat. no. 12-1331-82; eBioscience, San Diego, CA, USA) and rat anti-CD44-allophycocyanin antibody (clone IM7; 1:50; cat. no. 559250; BD Biosciences) were added to the experimental groups, and the same quantity of normal isotype IgG was added to the control groups. Following incubation at $4^{\circ} \mathrm{C}$ for $30 \mathrm{~min}$ in the dark, the cells were washed with PBS and subjected to flow cytometric analysis (Accuri C6).

RNA extraction and reverse transcription-polymerase chain reaction $(R T-P C R)$ analysis. RNA was extracted from cells using an RNeasy Total RNA system (Qiagen, Inc, Valencia, CA, USA) according to the manufacturer's protocol. The quantity and purity of the RNA were assessed by measuring the absorbance at 260 and $280 \mathrm{~nm}$. The cDNA was synthesized from total RNA $(2 \mu \mathrm{g})$ with oligo (dT) primers using an M-MLV reverse transcriptase first strand kit (Invitrogen; Thermo Fisher Scientific, Inc.). A $25 \mu \mathrm{l}$ PCR reaction contained $4 \mu \mathrm{l}$ cDNA, $2.5 \mu \mathrm{l}$ buffer, $1 \mu \mathrm{l}$ forward primer, $1 \mu \mathrm{l}$ reverse primer, $1 \mu \mathrm{l}$ dNTP, $1 \mu 1$ Taq DNA polymerase and $14.5 \mu 1$ DEPC water. The primers used were as follows: Octamer-binding transcription factor-4 (OCT-4), forward 5'-TGGGCTAGAGAAGGATGT GG-3' and reverse 5'-CTGGGAAAGGTGTCCCTGTA-3'; sex determining region Y-box 2 (SOX-2), forward 5'-GAACGC CTTCATGGTATGGT-3' and reverse 5'-TCTCGGTCTCGG ACAAAAGT-3'; GAPDH, forward 5'-GGTTGTCTCCTG CGACTTCA-3' and reverse 5'-TGGTCCAGGGTTTCTTAC TCC-3'. The PCR reaction conditions were as follows: $94^{\circ} \mathrm{C}$ for $5 \mathrm{~min}$, followed by 30 cycles of $94^{\circ} \mathrm{C}$ for $40 \mathrm{sec}, 61^{\circ} \mathrm{C}$ for $30 \mathrm{sec}$ and $72^{\circ} \mathrm{C}$ for $10 \mathrm{~min}$. The PCR products were analyzed on a $2 \%$ agarose gel with ethidium bromide. The gel images were analyzed using Image-Pro plus 6.0 software (Media Cybernetics, Inc. Rockville, MD, USA).

Spheroid colony formation assay. The cells were inoculated at a density of 5,000 cells/well in ultra-low attachment 6-well plates (Corning Incorporated, Corning, NY, USA). Stem cell culture medium ( $2 \mathrm{ml}$; Academy of Military Medical Sciences, Beijing, China) was added to each well. The plate was placed in humidified air at $37^{\circ} \mathrm{C}$ with $5 \% \mathrm{CO}_{2}$. Every 2 days, $1 \mathrm{ml}$ stem cell medium was added. The sphere formation of the cells was observed at 7 days under a fluoresence microscope (TE2000-U; Nikon Corporation, Tokyo, Japan).

In vivo tumorigenicity. The $\mathrm{ALDH}^{\text {high }}, \mathrm{ALDH}^{\text {low }}$ or $\mathrm{ALDH}^{\text {neg }}$ cells were suspended in PBS following sorting, adjusted to 500 or 5,000 cells per $50 \mu \mathrm{l}$, and then mixed with $50 \mu \mathrm{l}$ Matrigel (BD biosciences). The cells were injected subcutaneously into 6-week-old female 615 mice (Experimental Animal Center of PLA General Hospital, Beijing, China). These mice were maintained under barrier conditions on a $12 \mathrm{~h}$ light/dark cycle in a temperature room at $20-24^{\circ} \mathrm{C}$ with free access to food and water, and the growth of tumors was observed every week for 16 weeks. The tumor mass was monitored using a caliper and the mice were sacrificed by cervical dislocation at 16 weeks.

Statistical analysis. All data were analyzed using SPSS 19.0 statistical software (IBM SPSS, Armonk, NY, USA). Data 
A
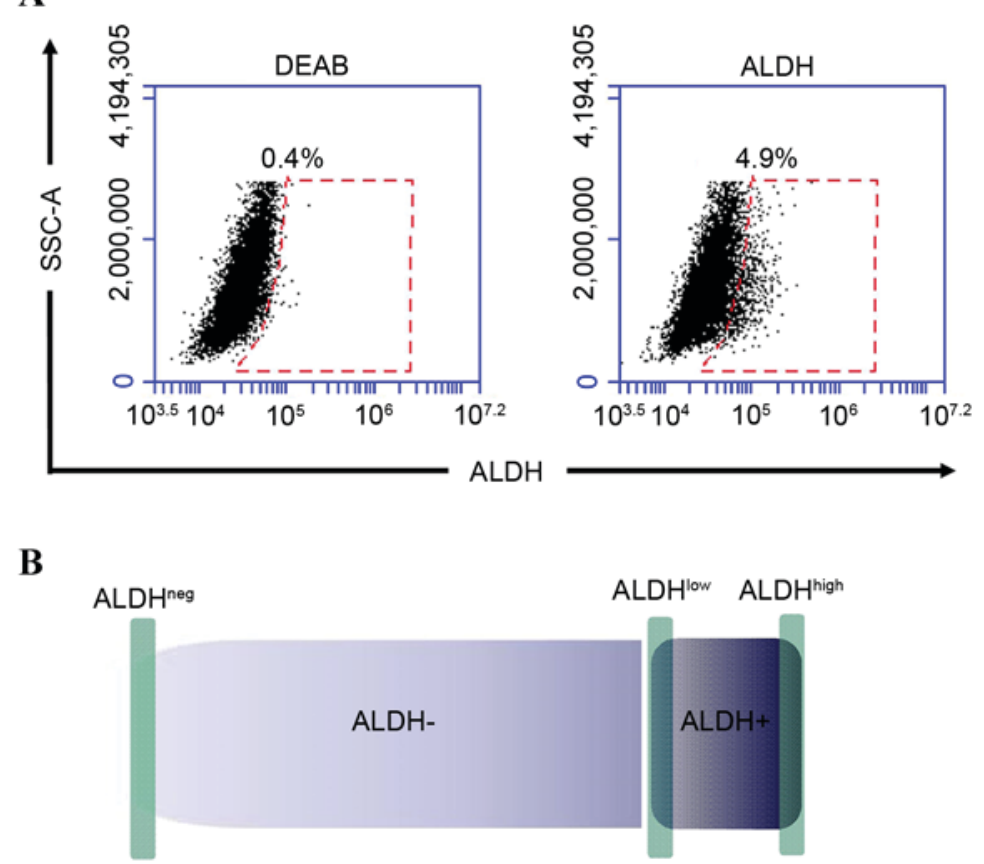

Figure 1. Detection of ALDH activity and cell sorting in MFC cells. (A) Expression of ALDH in MFC cells. (B) Diagrammatic sketch of cell sorting with different ALDH activities in MFC cells. The red lined boxes indicate ALDH ${ }^{+}$cells and percentages on the graphs indicate the rate of ALDH ${ }^{+}$cells. ALDH, aldehyde dehydrogenase; DEAB, diethylaminobenzaldehyde; SSC, side scatter.

are expressed as the mean \pm standard deviation from three independent experiments. Comparisons were made using an independent samples Student's $t$ test between two groups and by one-way analysis among multiple groups. $\mathrm{P}<0.05$ was considered to indicate a statistically significant difference.

\section{Results}

ALDH assay and cell sorting in MFC cells. The results of the flow cytometric analyses showed that the proportion of $\mathrm{ALDH}^{+}$ MFC cells was $5.12 \pm 0.91 \%$ (Fig. 1A), which was in accordance with the relatively low percentages of CSCs in tumors (21). In order to obtain cancer cells with different differentiation levels, the $1 \%$ of the cells with the highest fluorescence in the $\mathrm{ALDH}^{+}$population $\left(\mathrm{ALDH}^{\text {high }}\right)$ were selected and considered to be GCSCs. The $1 \%$ of the cells with the lowest fluorescence $\left(\mathrm{ALDH}^{\mathrm{low}}\right)$ were considered to be GCPCs and the $1 \%$ with the lowest fluorescence in the $\mathrm{ALDH}^{-}$population $\left(\mathrm{ALDH}^{\text {neg }}\right)$ were considered to be regular cancer cells (Fig. 1B).

Expression of stem cell surface markers in cells with different ALDH activities. In order to confirm the populations, the stem cell surface markers, CD $44^{+}$and $\mathrm{CD}_{133^{+}}{ }^{(22)}$ were detected in the different cell populations using flow cytometry. The results showed that $\mathrm{CD} 44^{+}$was expressed in $>90 \%$ of the total cell subpopulation, indicating that $\mathrm{CD} 44^{+}$may not be suitable as a stem cell marker in MFC cells (Fig. 2A). CD133+ was significantly higher in the $\mathrm{ALDH}^{\text {high }}(44.07 \pm 3.97 \%)$ and $\mathrm{ALDH}^{\text {low }}(34.33 \pm 3.06 \%)$ cells, compared with the ALDH ${ }^{\text {neg }}$ $(1.60 \pm 0.66 \%$ ) cells (high. vs. neg, $\mathrm{P}=0.007$; low, vs. neg, $\mathrm{P}=0.006)$. The expression of $\mathrm{CD} 133^{+}$was higher in the $\mathrm{ALDH}^{\text {high }}$ cells, compared with the $\mathrm{ALDH}^{\text {low }}$ cells, but this was not significantly different ( $\mathrm{P}=0.09$; Fig. $2 \mathrm{~B}$ and $\mathrm{C})$.
Gene expression in cells with different ALDH activity. In order to investigate the degree of differentiation of the cell subgroups, the relative expression of the stemness-associated genes OCT-4 (23) and SOX-2 (24) were examined using RT-PCR analysis. The results showed that the relative expression levels of OCT-4 were significantly higher in the ALDH ${ }^{\text {high }}$ $(1.02 \pm 0.07)$ and $\mathrm{ALDH}^{\text {low }}$ cells $(0.93 \pm 0.04)$, compared with the $\mathrm{ALDH}^{\text {neg }}(0.40 \pm 0.02)$ cells; $\mathrm{ALDH}^{\text {high }}$, vs. ALDH ${ }^{\text {neg. }}$ : $\mathrm{P}=0.001 ; \mathrm{ALDH}^{\text {low }}$, vs. ALDH ${ }^{\text {neg: }} \mathrm{P}<0.001$; Fig. $3 \mathrm{~A}$ and $\left.\mathrm{B}\right)$. The expression of OCT-4 in the ALDH ${ }^{\text {high }}$ cells was higher, compared with that in the ALDH ${ }^{\text {low }}$ cells, although this was not significant $(\mathrm{P}=0.331)$. A similar trend was observed for the expression of SOX-2. The ALDH ${ }^{\text {high }}(1.06 \pm 0.06)$ and $\mathrm{ALDH}^{\text {low }}$ $(0.90 \pm 0.05)$ cells had markedly higher expression of SOX-2, compared with the $\mathrm{ALDH}^{\text {neg }}(0.46 \pm 0.02)$ cells $\left(\mathrm{ALDH}{ }^{\text {high }}\right.$, vs. $\mathrm{ALDH}^{\text {neg. }} \mathrm{P}=0.003 ; \mathrm{ALDH}^{\text {low }}$, vs. $\left.\mathrm{ALDH}^{\text {neg }} ; \mathrm{P}=0.003\right)$, as shown in Fig. 3B. The expression of SOX-2 in the ALDH ${ }^{\text {high }}$ cells was higher, compared with that in the $\mathrm{ALDH}^{\text {low }}$ cells, although this was not significant $(\mathrm{P}=0.053)$.

Sphere formation in cells with differing ALDH activity. To assess the sphere-forming ability of cells with differing ALDH activity, $\mathrm{ALDH}^{\text {high }}, \mathrm{ALDH}^{\text {low }}$ or $\mathrm{ALDH}^{\text {neg }}$ cells were cultured under ultra-low adhesion conditions without serum. The results showed that $\mathrm{ALDH}{ }^{\text {high }}$ and $\mathrm{ALDH}^{\text {low }}$ cells formed tumor spheres following 7 days in culture, however, $\mathrm{ALDH}^{\text {neg }}$ cells did not form spheres. The tumor sphere volumes of the $\mathrm{ALDH}^{\text {high }}$ cells were significantly lower, compared with those of the $\mathrm{ALDH}^{\text {low }}$ cells (Fig. 4A). The ALDH activity assays demonstrated that the percentage of $\mathrm{ALDH}^{+}$cells in the spheres formed by $\mathrm{ALDH}^{\text {low }}$ cells was significantly lower, compared with the percentage in the $\mathrm{ALDH}^{\text {high }}$ cell spheres (30.5 \pm 5.7 , vs. $70.1 \pm 7.1 \%$, respectively; $\mathrm{P}<0.001$; Fig. $4 \mathrm{~B}$ and $\mathrm{C}$ ). 

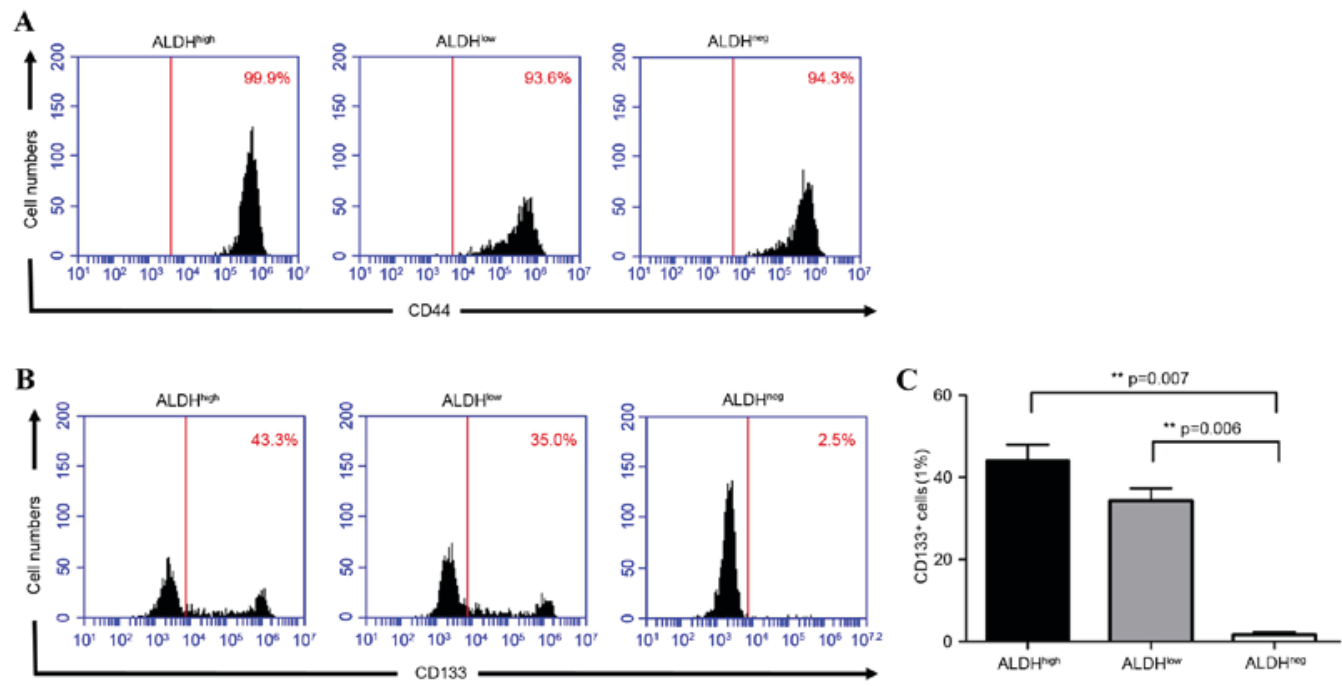

Figure 2. Flow cytometric analysis. Expression levels of (A) $\mathrm{CD}_{4} 4^{+}$and (B) $\mathrm{CD} 133^{+}$in cells with different ALDH activity are shown. The percentages in (A) indicate $\mathrm{CD} 44^{+}$cells in the groups of cells with different ALDH activity. The percentages in (B) indicate CD133 ${ }^{+}$cells in the groups of cells with different ALDH activity. (C) Statistical analysis of the expression of $\mathrm{CD} 133^{+}$. ALDH, aldehyde dehydrogenase.
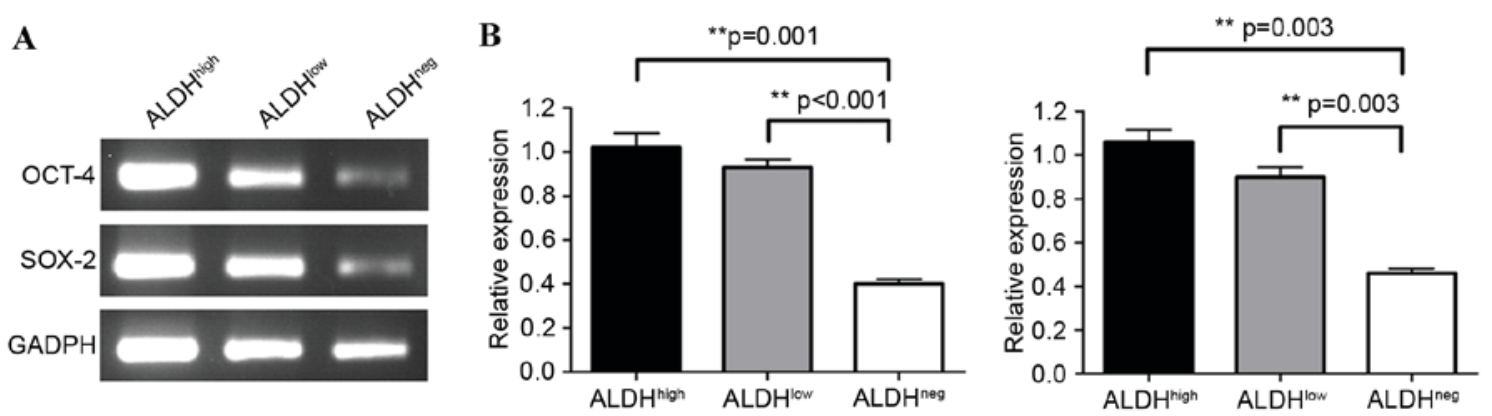

Figure 3. Expression levels of OCT-4 and SOX-2. (A) mRNA expression levels of OCT-4 and SOX-2 in cells with different ALDH activity. (B) Statistical analysis of the relative mRNA expression of OCT-4 (left) and SOX-2 OCT-4 (right). ALDH, aldehyde dehydrogenase; OCT-4 octamer-binding transcription factory-4; SOX-2, sex determining region Y-box 2.

Tumor formation in cells with differing ALDH activity in mice. In order to assess the tumor-forming ability of cells with differing ALDH activity, the sorted cells were subcutaneously injected in mice at different concentrations (500 and 5,000 cells per $50 \mu \mathrm{l}$ PBS) to observe tumor formation. The results are shown in Table I. Tumors appeared 4 weeks following the injection of 5,000 cells and tumor formation was observed in all mice at 8 weeks in the $\mathrm{ALDH}^{\text {low }}$ group. Of the six transplanted mice, four developed tumors 16 weeks following the injection of 5,000 cells in the $\mathrm{ALDH}^{\text {high }}$ group, and only one mouse developed tumors 16 weeks following injection of 5,000 cells in the $\mathrm{ALDH}^{\text {neg }}$ group. However, when the injected number of cells was decreased to 500, tumors first appeared in the ALDH ${ }^{\text {low }}$ group 8 weeks following injection. The rate of tumor formation in the $\mathrm{ALDH}^{\text {high }}$ group was higher, compared with that in the $\mathrm{ALDH}^{\text {low }}$ group with extended duration, and no tumors formed in the $\mathrm{ALDH}^{\text {neg }}$ group.

\section{Discussion}

In the present study, it was shown that the expression of the stemness-associated markers, CD133+, OCT- 4 and SOX-2,
Table I. Tumor formation in mice injected with cells of differing ALDH activity.

Mice with tumors (n)

Cell type Cells (n) 4 weeks 8 weeks 12 weeks 16 weeks

\begin{tabular}{lrllll}
\hline ALDH $^{\text {high }}$ & 5,000 & 0 & 1 & 2 & 4 \\
ALDH $^{\text {low }}$ & 5,000 & 3 & 6 & 6 & 6 \\
ALDH $^{\text {neg }}$ & 5,000 & 0 & 1 & 1 & 1 \\
ALDH $^{\text {high }}$ & 500 & 0 & 0 & 1 & 3 \\
ALDH $^{\text {low }}$ & 500 & 0 & 1 & 1 & 1 \\
ALDH $^{\text {neg }}$ & 500 & 0 & 0 & 0 & 0
\end{tabular}

$\mathrm{n}=6$ mice per group. ALDH, aldehyde dehydrogenase.

decreased with a decrease in ALDH activity in MFC cells. The $\mathrm{ALDH}^{\text {high }}$ and $\mathrm{ALDH}^{\text {low }}$ cells formed tumor spheres, however the $\mathrm{ALDH}^{\text {low }}$ cells formed larger tumor spheres. In mice transplanted with 5,000 cells, the rate of tumor formation in the $\mathrm{ALDH}^{\text {low }}$ group was significantly higher, compared 
A
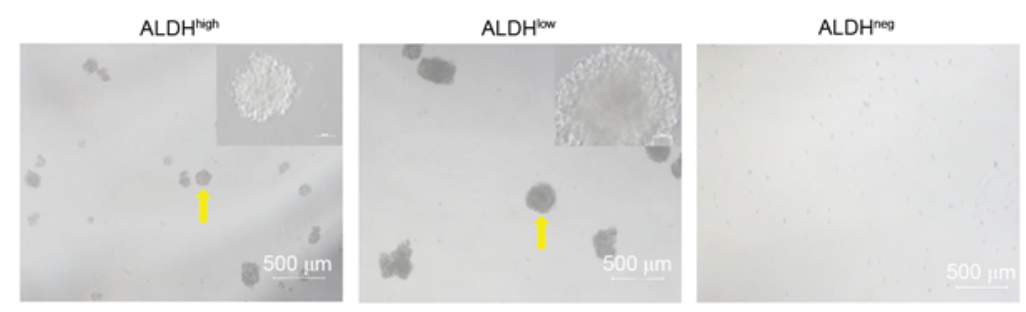

B

ALDH
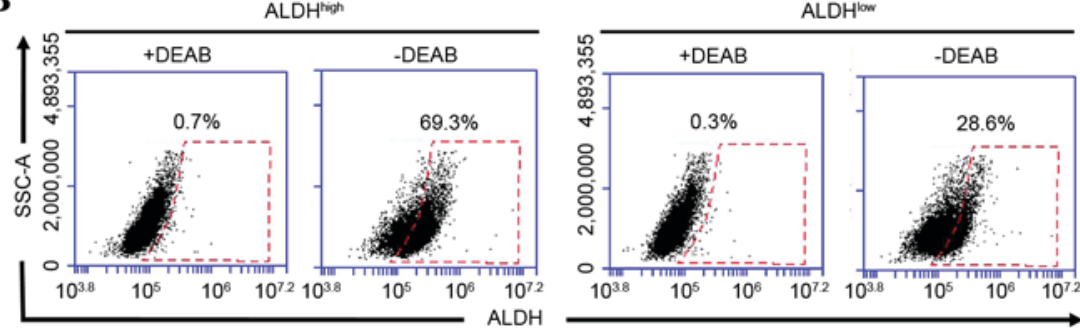

C

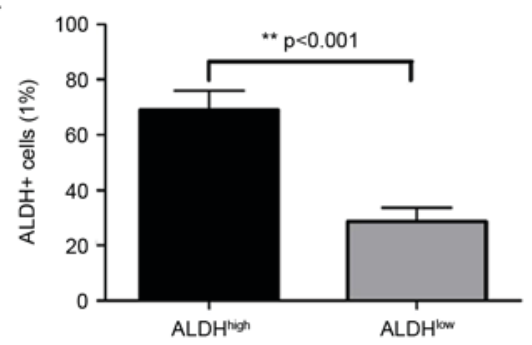

Figure 4. Sphere formation in vitro. (A) Sphere formation of cells with different ALDH activities. The arrows indicate the enlarged tumor spheres. Overall magnification, $\mathrm{x} 40$; local magnification, $\mathrm{x} 400$. (B) Detection of ALDH activity in the spheres and (C) quantification. The red lined boxes indicate ALDH cells and percentages on the graphs indicate the rate of $\mathrm{ALDH}^{+}$cells. ALDH, aldehyde dehydrogenase; DEAB, diethylaminobenzaldehyde; SSC, side scatter.

with that in the ALDH ${ }^{\text {high }}$ group. On injection of the mice with 500 cells, tumor development was delayed, however, more mice developed tumors in the ALDH ${ }^{\text {high }}$ group, compared with the $\mathrm{ALDH}^{\text {low }}$ group. These results demonstrated that ALDH ${ }^{\text {high }}$ cells had the characteristics of GCSCs and ALDH ${ }^{\text {low }}$ cells had the characteristics of GCPCs. These findings suggested that the separation of GCPCs from GCSCs may be important to elucidate the biology of GCSCs and for developing strategies to eliminate GCSCs for the treatment of patients with GC.

The theory of CSCs suggests that tumor cells have a differentiation level similar to that of stem cells (8). Undifferentiated CSCs initially generate CPCs and then further differentiate into regular cancer cells. Although CPCs are important in tumor cells, few studies have systematically investigated CPCs, and there are no reports distinguishing CSCs from CPCs in GC. To the best of our knowledge, only the study by Beier et al (25) and our previous study have sorted CPCs. Our previous study sorted CPCs in H22 cells using an ALDH activity assay (20). Beier et al (25) reported the successful isolation of CD133- cerebral glioma CPCs from $\mathrm{CD}_{133^{+}}$cerebral glioma CSCs under conditions of stem cell cultivation. However, they did not show the percentage of CSCs in the $\mathrm{CD}_{133^{+}}$cells, therefore, it is possible that CD133- cerebral glioma CPCs also contain regular cancer cells. In our previous study stemness-like cells were distinguished according to CSC sorting methods including, stemness-associated marker sorting, sphere enrichment (21), SP sorting (4) and ALDH activity sorting (26). Although stemness-assocated marker sorting is the most common way to isolate CSCs, it is not able to further distinguish CPCs from the selected CSCs. Sphere enrichment is a useful method by itself, however, the cells in the formed sphere may contain regular cancer cells (27). The SP method is another way to sort CSCs, however it requires the chemical, Hoechst 33342, which is cytotoxic and may affect the reliability of the data. ALDH is important in stem cell differentiation and proliferation. ALDH activity reflects the degree of stemness of stem cells and has been used as a functional stem cell marker in sorting various types of CSC (14-19). Consistent with the findings of the present study, Katsuno et al (28) found that the tumor formation of $\mathrm{ALDH}^{+} \mathrm{GC}$ cells is more marked, compared with that of $\mathrm{ALDH}^{-} \mathrm{GC}$ cells in GC tissues and cell lines. In addition, Zhi et al (29) successfully acquired a GC stem-like cell population via ALDH activity detection. These findings indicate that ALDH may be a reliable marker for the acquisition of GCSCs.

The results of the present study showed that $\sim 5 \%$ of the MFC cells were $\mathrm{ALDH}^{+}$in the total cell population, which is in accordance with the low percentage of CSCs in solid tumors (21). Consequently, $\mathrm{ALDH}^{+}$cells were defined as stem-like cells and $\mathrm{ALDH}^{-}$cells were defined as non-stemess cells. In order to isolate GCSCs and GCPCs from the stem-like cell population, our previously reported ALDH activity assay was used (20). The $1 \%$ of the $\mathrm{ALDH}^{+}$cells with the highest activity were selected and considered to be GCSCs. Although a subset of GCSCs in the $\mathrm{ALDH}^{+}$cells may be missed in the low 
proportion selection method, cells acquired from the selection are more accurate and the data are more reliable. In addition, the $1 \%$ of $\mathrm{ALDH}^{+}$cells with the lowest activity were selected and considered to be GCPCs, as its degree of stemness was the weakest of the $\mathrm{ALDH}^{+}$cells and close to non-stemness cells $\left(\mathrm{ALDH}^{-}\right)$at the differentiated stage of CPCs (30). Finally, the $1 \%$ of the $\mathrm{ALDH}^{-}$cells with the lowest activity were selected and defined as regular cancer cells.

Further analyses of the stemness-associated markers revealed that $\mathrm{CD}_{4} 4^{+}$was expressed at high levels in all three cell subpopulations, suggesting that $\mathrm{CD}_{4} 4^{+}$was not a suitable marker for MFC cells; however, the levels of CD133+, OCT-4 and SOX-2 decreased with a decrease in ALDH activity, and were lowest in the $\mathrm{ALDH}^{\text {neg }}$ cells. These results suggested that the activity of ALDH was positively correlated with the degree of stemness in the MFC cells, with the $\mathrm{ALDH}^{\text {high }}$ and $\mathrm{ALDH}^{\text {low }}$ cells being stem-like cells, and $\mathrm{ALDH}^{\text {neg }}$ cells being regular cancer cells.

A sphere formation assay is one of the classic methods for detecting CSCs (6). The present study found that $\mathrm{ALDH}^{\text {high }}$ and $\mathrm{ALDH}^{\text {low }}$ cells formed tumor spheres, which suggested that the two types of cells have a certain degree of self-renewal ability. However, the volumes of the spheres were considerably lower for the $\mathrm{ALDH}^{\text {high }}$ cells, compared with the $\mathrm{ALDH}^{\text {low }}$ cells. In addition, the percentage of $\mathrm{ALDH}^{+}$cells in the spheres formed by the $\mathrm{ALDH}^{\text {low }}$ cells was significantly lower, compared with the spheres formed by the ALDH ${ }^{\text {high }}$ cells. These results suggested that $\mathrm{ALDH}^{\text {low }}$ cells formred larger tumor spheres with a large number of $\mathrm{ALDH}^{-}$cells, consistent with the lower self-renewal but rapid differentiation abilities of CPCs. By contrast, the ALDH ${ }^{\text {high }}$ sphere cells were comprised predominantly of $\mathrm{ALDH}^{+}$cells, suggesting that tumor spheres are generated by self-renewal. In addition, the volumes of the spheres were relatively low, indicating stable and slow proliferation of ALDH ${ }^{\text {high }}$ cells, a typical characteristic of CSCs (21). However, ALDH ${ }^{\text {high }}$ and $\mathrm{ALDH}^{\text {low }}$ cells formed spheres under certain conditions, providing evidence that the purity of CSCs is low by sphere enrichment.

Various studies have suggested that CSCs have higher tumor-forming abilities, compared with other cell subpopulations $(4,6,21)$. However, other studies have reported opposite results. Read et al (31) found that tumor-forming cells express markers of neural progenitor cells rather than stem cell markers in a mouse model of medulloblastoma . Ucar et al (17) found that the time for in vivo tumor formation of H522 cells with high ALDH activity is significantly longer, compared with that of cells with low ALDH activity.

Combined with the results of the present study, several novel perspectives have been suggested. The proportions of CSCs and CPCs are low in solid tumors, and CSCs in a resting state do not exhibit tumor formation ability in a short duration (21). However, tumors with pathological significance require numerous regular cancer cells to obtain a certain volume. Consequently, if the observational period is not long enough, it is possibly to falsely conclude that CSCs do not have stemness-associated properties. Although CPCs have limited self-renewal ability, they proliferate rapidly (27). When certain numbers of CPCs (5,000 $\mathrm{ALDH}^{\text {low }}$ cells) were injected into mice, they showed high tumor-forming ability, as CPCs generate large numbers of regular cancer cells. When fewer tumor cells (500 $\mathrm{ALDH}^{\text {high }}$ cells) were injected into mice, CSCs demonstrated a high tumor-forming ability when the observation period was long enough. However, mice injected with CPCs showed weaker tumor formation ability, compared with the CSC group, although tumors formed at an early stage in the CPC group, possibly due to the limited self-renewal ability of CPCs. The characteristics of $\mathrm{ALDH}^{\text {neg }}$ cells were in accordance with those of regular cancer cells, with no self-renewal ability and limited proliferative ability (27). Therefore, tumor formation ability was significantly lower, compared with that of $\mathrm{ALDH}^{\text {high }}$ and $\mathrm{ALDH}^{\text {low }}$ cells. Thus, it was hypothesized that CSCs, CPCs and regular cancer cells are cell subpopulations with differing differentiation stages and different proliferative abilities in tumor tissues.

In conclusion, the results of the present study suggested that GCSCs and GCPCs are two stem-like subgroups with different characteristics, and these two subgroups exist in the stem-like cells of MFC cells. Excluding GCPCs from stem-like cells to achieve a higher purity of GCSCs may benefit future investigations of GCSCs and CSCs.

\section{Acknowledgements}

The present study was supported by the Natural Science Foundation of China (grant no. 81,172,891).

\section{References}

1. Parkin DM, Bray F, Ferlay J and Pisani P: Global cancer statistics, 2002. CA Cancer J Clin 55: 74-108, 2005.

2. Hohenberger P and Gretschel S: Gastric cancer. Lancet 362: 305-315, 2003.

3. Polyak K and Hahn WC: Roots and stems: Stem cells in cancer. Nat Med 12: 296-300, 2006.

4. Fukuda K, Saikawa Y, Ohashi M, Kumagai K, Kitajima M, Okano H, Matsuzaki Y and Kitagawa Y: Tumor initiating potential of side population cells in human gastric cancer. Int J Oncol 34: 1201-1207, 2009.

5. Zhang H, Xi H, Cai A, Xia Q, Wang XX, Lu C, Zhang Y, Song Z, Wang H, Li Q, et al: Not all side population cells contain cancer stem-like cells in human gastric cancer cell lines. Dig Dis Sci 58: 132-139, 2013.

6. Takaishi S, Okumura T, Tu S, Wang SS, Shibata W, Vigneshwaran R, Gordon SA, Shimada Y and Wang TC: Identification of gastric cancer stem cells using the cell surface marker CD44. Stem Cells 27: 1006-1020, 2009.

7. Rocco A, Liguori E, Pirozzi G, Tirino V, Compare D, Franco R, Tatangelo F, Palaia R, D'Armiento FP, Pollastrone G, et al: CD133 and CD44 cell surface markers do not identify cancer stem cells in primary human gastric tumors. J Cell Physiol 227: 2686-2693, 2012.

8. Beck B and Blanpain C: Unravelling cancer stem cell potential. Nat Rev Cancer 13: 727-738, 2013.

9. Chute JP, Muramoto GG, Whitesides J, Colvin M, Safi R, Chao NJ and McDonnell DP: Inhibition of aldehyde dehydrogenase and retinoid signaling induces the expansion of human hematopoietic stem cells. Proc Natl Acad Sci USA 103: 11707-11712, 2006.

10. Collins SJ: Retinoic acid receptors, hematopoiesis and leukemogenesis. Curr Opin Hematol 15: 346-351, 2008.

11. Estes BT, Wu AW, Storms RW and Guilak F: Extended passaging, but not aldehyde dehydrogenase activity, increases the chondrogenic potential of human adipose-derived adult stem cells. J Cell Physiol 209: 987-995, 2006.

12. Muramoto GG, Russell JL, Safi R, Salter AB, Himburg HA, Daher P, Meadows SK, Doan P, Storms RW, Chao NJ, et al: Inhibition of aldehyde dehydrogenase expands hematopoietic stem cells with radioprotective capacity. Stem Cells 28: 523-534, 2010.

13. Sladek NE: Human aldehyde dehydrogenases: Potential pathological, pharmacological, and toxicological impact. J Biochem Mol Toxicol 17: 7-23, 2003. 
14. Burger PE, Gupta R, Xiong X, Ontiveros CS, Salm SN, Moscatelli D and Wilson EL: High aldehyde dehydrogenase activity: A novel functional marker of murine prostate stem/progenitor cells. Stem Cells 27: 2220-2228, 2009.

15. Clay MR, Tabor M, Owen JH, Carey TE, Bradford CR, Wolf GT, Wicha MS and Prince ME: Single-marker identification of head and neck squamous cell carcinoma cancer stem cells with aldehyde dehydrogenase. Head Neck 32: 1195-1201, 2010.

16. Lingala S, Cui YY, Chen X, Ruebner BH, Qian XF, Zern MA and $\mathrm{Wu} \mathrm{J}$ : Immunohistochemical staining of cancer stem cell markers in hepatocellular carcinoma. Exp Mol Pathol 89: 27-35, 2010.

17. Ucar D, Cogle CR, Zucali JR, Ostmark B, Scott EW, Zori R, Gray BA and Moreb JS: Aldehyde dehydrogenase activity as a functional marker for lung cancer. Chem Biol Interact 178: 48-55, 2009.

18. van den Hoogen C, van der Horst G, Cheung H, Buijs JT, Lippitt JM, Guzmán-Ramírez N, Hamdy FC, Eaton CL, Thalmann GN, Cecchini MG, et al: High aldehyde dehydrogenase activity identifies tumor-initiating and metastasis-initiating cells in human prostate cancer. Cancer Res 70: 5163-5173, 2010.

19. Deng S, Yang X, Lassus H, Liang S, Kaur S, Ye Q, Li C, Wang LP, Roby KF, Orsulic S, et al: Distinct expression levels and patterns of stem cell marker, aldehyde dehydrogenase isoform 1 (ALDH1), in human epithelial cancers. PLoS One 5: e10277, 2010.

20. Ding Y, Liang W and $\mathrm{Hu} \mathrm{X}$ : Analysis of heterogenous distribution of different stem characteristic subset in H22 cells. Armed Police Med 23: 415-418, 2012.

21. Boman BM and Wicha MS: Cancer stem cells: A step toward the cure. J Clin Oncol 26: 2795-2799, 2008.

22. Quante M and Wang TC: Stem cells in gastroenterology and hepatology. Nat Rev Gastroenterol Hepatol 6: 724-737, 2009.
23. Koo BS, Lee SH, Kim JM, Huang S, Kim SH, Rho YS, Bae WJ, Kang HJ, Kim YS, Moon JH and Lim YC: Oct4 is a critical regulator of stemness in head and neck squamous carcinoma cells. Oncogene 34: 2317-2324, 2015

24. Tam WL and Ng HH: Sox2: Masterminding the root of cancer. Cancer Cell 26: 3-5, 2014.

25. Beier F, Beier CP, Aschenbrenner I, Hildebrandt GC, Brümmendorf $\mathrm{TH}$ and Beier D: Identification of CD133(-)/telomerase(low) progenitor cells in glioblastoma-derived cancer stem cell lines. Cell Mol Neurobiol 31: 337-343, 2011.

26. Marcato P, Dean CA, Giacomantonio CA and Lee PW: Aldehyde dehydrogenase: Its role as a cancer stem cell marker comes down to the specific isoform. Cell Cycle 10: 1378-1384, 2011.

27. Beier D, Hau P, Proescholdt M, Lohmeier A, Wischhusen J, Oefner PJ, Aigner L, Brawanski A, Bogdahn U and Beier CP: CD133(+) and CD133(-) glioblastoma-derived cancer stem cells show differential growth characteristics and molecular profiles. Cancer Res 67: 4010-4015, 2007.

28. Katsuno Y, Ehata S, Yashiro M, Yanagihara K, Hirakawa K and Miyazono K: Coordinated expression of REG4 and aldehyde dehydrogenase 1 regulating tumourigenic capacity of diffuse-type gastric carcinoma-initiating cells is inhibited by TGF- $\beta$. J Pathol 228: 391-404, 2012.

29. Zhi QM, Chen XH, Ji J, Zhang JN, Li JF, Cai Q, Liu BY, Gu QL, Zhu ZG and Yu YY: Salinomycin can effectively kill ALDH(high) stem-like cells on gastric cancer. Biomed Pharmacother 65: 509-515, 2011.

30. Bosch X: Bone-marrow-derive cells implicated in gastric cancer. Lancet Oncol 6: 8, 2005.

31. Read TA, Fogarty MP, Markant SL, McLendon RE, Wei Z, Ellison DW, Febbo PG and Wechsler-Reya RJ: Identification of CD15 as a marker for tumor-propagating cells in a mouse model of medulloblastoma. Cancer Cell 15: 135-147, 2009. 